\title{
Abuela Julieta. Xamanismo contemporâneo em Huautla
}

Este artigo analisa o xamanismo contemporâneo em Huautla baseado no estudo de caso da abuela Julieta Casimiro, uma das mais conhecidas xamã da cidade, com quem tive a oportunidade de trabalhar por mais de sete meses durante o trabalho campo. Nossa apresentação será dividida em três seções que apresentam dados de natureza diferente. Na primeira seção, apresentamos um resumo da história da abuela Julieta. A segunda seção sistematiza informações que resultam da observação direta, tendo acompanhado dezenas de rituais sagrados com 'niños santos' e participado como assistente em algumas ocasiões. Na terceira seção me aproximo do meu próprio aprendizado ao longo desta experiência etnográfica, uma etnografia dos estados de consciência em rituais com 'niños santos'.

Xamanismo, Rituais, Xamanismo contemporâneo, Mazatecos.

'Você pode ser muito crítico ou entender' Jean Langdon.

In memoriam Abuela Julieta Casimiro

$(1936-2018)$

\section{Huautla e seus xamãs}

Quando alguém chega a Huautla, é recebido por uma estátua de María Sabina, de pé sobre um cogumelo de três metros de altura. María Sabina e os rituais com cogumelos alucinantes fazem parte da

a Professor Associado do Programa de Pós-Graduação em Antropologia Social, Faculdade de Ciências Sociais, Universidade Federal de Goiás (PPGAS/FCS/ UFG). Email: gabriel.o.alvarez@gmail.com. 
identidade da cidade. A maioria dos estrangeiros que chegaram foi atraída pela figura da xamã Mazateca que revelou o ritual das 'meninos santos' para estrangeiros. A figura de Maria Sabina e o cogumelo como símbolo podem ter significados diferentes para os mazatecos e para os viajantes.

Maria Sabina (1894-1985) foi o xamã retratado por Wasson (1957) que se tornou um símbolo da cultura popular psicodélica. Como a Virgem de Guadalupe, Maria Sabina como símbolo articula diferentes significados para diferentes segmentos da população. Para os estrangeiros, Maria Sabina era o arquétipo do xamã psicodélico; para os mazatecos era abuela, uma chjota-chjine, uma pessoa do conhecimento. Para os estrangeiros, Maria Sabina tornou-se um ícone do xamanismo, mas ao mesmo tempo se perdeu o contexto da tradição mazateca, que permite entender esta manifestação específica do xamanismo. Maria Sabina tornou-se um símbolo de Huautla, como indicado pelas múltiplas reproduções de seus retratos e sua enorme estátua acima de um cogumelo com vários metros de altura. Foi a disseminação dos rituais de María Sabina que atraiu milhares de hippies na década de 1960, e hoje continua a atrair turistas. Chjota-chjine é uma categoria mazateca que pode ser traduzida por xamã mas tem sua especificidade na tradição mazateca (Alvarez 2017; Manrique Rosado 2013).

$\mathrm{O}$ artigo de Wasson e os escritos de Castaneda transformaram Huautla na Meca do movimento psicodélico, que alguns classificam como neo-xamanismo. Milhares de hippies foram a Huautla para experimentar os cogumelos alucinantes. Os jovens viajavam para realizar um ritual com Maria Sabina ou com outros xamãs da região. Hoje, os turistas da Nova Era continuam chegando interessados em participar de rituais com 'meninos santos' (niños santos). Atualmente, 25 xamãs oferecem esse serviço ao público que visita à cidade.

Os trabalhos de Castaneda (2001) imprimiram um renovado interesse no assunto, encontrando terreno fértil na contestação cultural inspirada por autores da contracultura, como Timothy Leary, William Burroughs, Aldous Huxley entre outros. A publicação de 
Wasson (1957) sobre María Sabina em Huautla revelou o local onde era possível experimentar rituais com plantas de poder. Esse fenômeno transformou Huautla em destino de viajantes de diferentes partes do mundo interessados em conhecer os rituais. Alguns autores chamam esse encontro de jovens ocidentais com rituais tradicionais de neo-xamanismo (Rodriguez 2016; Demanget 2000).

Mircea Eliade (1976) constrói o xamanismo como uma categoria analítica, com o objetivo de demarcar o fenômeno religioso como diferente dos cultos de possessão e das liturgias das religiões salvacionistas. Mircea Eliade se concentra no xamanismo como um transe alcançado por meio de técnicas de êxtase, através das quais o xamã enfrenta seres extraordinários com o objetivo de restaurar a saúde do paciente. Essas viagens incluem incursões no supramundo e no inframundo, incursão em outros planos da realidade para alterar o que acontece no plano vivido. Essa construção analítica tomou como caso exemplar o xamanismo siberiano, mas sua aplicação se estendeu a outras sociedades em diferentes continentes.

Podemos pensar no xamanismo como um tipo de comunicação com o sagrado, que não contradiz outras formas religiosas e muitas vezes coexiste com elas. $O$ xamã não é louco nem desequilibrado, pelo contrário, é um profundo conhecedor da tradição cultural. Tanto nas planícies da América do Sul quanto no México, o xamanismo estava relacionado ao poder político. $\mathrm{O}$ xamanismo não é uma religião de grupos primitivos (Bartolomé \& Barabas 2013, Langdon 1992).

Bartolomé \& Barabas (2013) caracterizam o xamanismo no México: "O xamanismo como mediação com o extra-humano, o nahualismo como capacidade de transformação e a jornada onírica como um instrumento para ligar duas ou mais realidades [...]" (Bartolomé \& Barabas 2013:15). Para esses autores, o xamã é o depositário de um conjunto de conhecimentos e práticas que são construções ideológicas de suas sociedades. Mircea Eliade trabalhou o xamanismo como técnicas de êxtase, através das quais entra em contato com os deuses. Bartolomé \& Barabas (2013) assinalaram que todo transe é vivido 
como um sonho em um sentido amplo. Para esses autores, o xamanismo deve ser interpretado como uma instituição com lógica específica e grande dinamismo, eficaz em vários contextos históricos (Bartolomé \& Barabas 2013:41). Voltando a Mauss (2003), poderíamos dizer que o xamanismo é uma técnica tradicional e eficaz.

A categoria de xamanismo carrega um certo colonialismo como categoria de classificação, ao tratar da mesma forma diferentes performance do xamanismo em diversas tradições. Paradoxalmente, a categoria neo-xamanismo carrega um certo estigma, como se fosse um xamanismo não autêntico. Langdon $(2013,2016)$ observa a necessidade de superar esses julgamentos de valor para pensar sobre esse campo que surge do encontro do xamanismo com o público ocidental como diversas performances do xamanismo, um fenômeno que dificilmente pode ser considerado uniforme. Langdon propõe a aplicação do termo xamanismo contemporâneo para analisar essas novas manifestações do xamanismo e analisá-las como um gênero performativo.

Atkinson (1992) DuBois (2011), em seus trabalhos sobre o xamanismo, aponta para a crescente importância dos fenômenos neo-xamanistas com o público New Age. Se, em alguns casos, o neo-xamanismo aparece como uma mimese do xamanismo em contextos ocidentais, estes movimentos também procuram a participação de xamãs tradicionais como um índice de legitimidade. Joralemon (1990), que trabalhou no Peru com xamanismo e público New Age explora as ambiguidades de trabalhar com curandeiros tradicionais que ganham projeção internacional. $\mathrm{O}$ autor também explora os preconceitos dos antropólogos ao trabalhar nesses contextos de estranho cosmopolitismo.

Os rituais foram pensados na antropologia como poderosos aparelhos comunicacionais que operam ao interior de uma tradição cultural. A escola francesa focou a ideia de eficácia nessa relação entre ritual e tradição como representações coletivas (Durkheim 1989; Mauss, 2003; Lévi-Strauss 1967).

O que acontece quando o ritual opera entre diferentes tradições culturais? Taussig (1987) trabalhou no xamanismo indígena em Cau- 
ca em contextos que incluíam pacientes mestiços. Langdon propõe analisar o xamanismo como um modo performático. Nesta perspectiva, o desempenho é o produto da interação e das expectativas das diferentes partes envolvidas: o xamã, o paciente (tradicional ou não tradicional) e o público. Toda participação é uma participação expectante. Essa abordagem permite a contextualização de rituais nos quais os membros participam de diferentes tradições culturais e têm diferentes horizontes de expectativas.

Neste trabalho, focamos em rituais com 'meninos santos', a face mais visível do xamanismo mazateca, aberta ao turismo místico. Trabalhamos com a abuela Julieta Casimiro, a xamã mais reconhecida em Huautla. Nossa preocupação com a investigação não era classificar ou julgar o xamanismo contemporâneo em Huautla. Nosso objetivo com esta etnografia era compreender esses rituais para traduzir essa experiência para um público mais amplo.

\section{Abuela Julieta}

Cheguei a Huautla alguns dias antes da festa dos mortos. Passei alguns dias no hotel, conhecendo a cidade. À medida que a festa se aproxima, os turistas chegam e muitos migrantes mazateco retornam a Huautla para passar a festa com suas famílias, vivos e mortos. Os quartos do hotel estavam todos reservados. A dona da barraca onde bebia meu café da manhã, uma mazateca evangélica, me informou que atrás da escola fica a casa de uma senhora que aluga quartos para estrangeiros que visitam a cidade.

Quando cheguei ao local indicado, uma mulher mazateca de 80 anos me recebeu na porta. Seus olhos tinham um brilho especial, de alguma forma me lembrou Maria Sabina. Ela me informou do preço dos quartos e perguntou se eu estava interessado em experimentar os 'meninos santos'. Respondo que estou interessado, mas que, segundo a literatura, o ritual não deve ser realizado durante a festa dos mortos. Ela olhou para mim, com brilho nos olhos, me mostrou seu Devocionário Mazateco e me disse que seguia as orientações do livro, que não haveria problemas. Ela terminou sua apresentação dizendo-me que é a 13a abuela do conselho das abuelas do mundo e mostrou a foto onde aparece junto com as outras abue- 
las xamãs, de diferentes partes do globo: Estados Unidos, Alasca, Japão, Tibete, África, Brasil....

Foi assim que conheci a abuela Julieta, por casualidade ou causalidade. Meses depois, ela me disse que tinha me visto na cidade antes de chegar na casa. "Você estava na porta da igreja, conversando com Aurelio, sua energia estava toda torta." Aurélio, que vende velas, copal e cacau na porta da igreja, foi um dos meus primeiros contatos em Huautla. Assim começou meu relacionamento com a abuela Julieta, uma das xamãs mais reconhecidas de Huautla, de quem me tornei filho espiritual.

Aluguei um quarto na casa da abuela Julieta até o final da primeira viagem, cerca de 15 dias. Durante esse período, pude observar as rotinas da casa: as conversas ao redor do fogão, os convidados que vieram participar das cerimônias com a abuela Julieta, as regras rígidas que as filhas da abuela tentam impor à casa. Sem bebidas alcoólicas, sem fumar nos quartos, não chegar bêbado de madrugada. Sexo nem pensar, esta é uma casa de cura, tem que estar limpa, como um templo.

Durante a segunda viagem, que durou pouco mais de sete meses, aluguei um quarto com banheiro e entrada separada no bairro de La Cruz, acima do centro. Durante esse período, eu frequentava a casa da abuela Julieta quase todas as manhãs, acompanhava Dona Julieta nas mayordomias e à noite participava dos rituais com 'meninos santos'.

Julia Julieta Pineda Casimiro tem 80 anos. Seus pais, Maclobio Casimiro Martín e María Petra Estrada García, tiveram 9 filhos. Julia Julieta Casimiro nasceu em Colonia Plan de Carril, Huautla de Jiménez, em um local chamado Mazateco n'da jin, 'água suficiente'. Em 1952, aos 16 anos, casou-se com Lucio Pineda, que tinha 30 anos na época. Essa diferença de idade é comum na Mazateca. Lucio era filho de Librado Pineda e Regina Carrera Calvo. O pai de Lúcio foi morto 
em um episódio confuso em Ayautla em 1928. Dona Regina, que era da baixa Mazateca, permaneceu em Huautla nas terras da família. Quando Lucio voltou da Cidade do México, com 30 anos, casou-se com Julia Julieta Casimiro.

"Eu era menina, não sabia de nada", diz abuela Julieta. "Dona Regina foi como uma mãe para mim. Eu a acompanhava para pegar café, ajudava com as coisas da casa. Uma vez ela me disse para encontrá-la à noite, em frente ao altar da casa. Meu marido, Lucio sinalizou para eu ir. Ele já estava sabendo. Foi lá que Dona Regina me ensinou a trabalhar com meninos santos."

Dona Gonzala, filha de Dona Regina, irmã mais velha de Lúcio, também realizava rituais com 'meninos santos'. Incháustegui, fundador do Centro Coordenador Indigenista do INI, experimentou os 'meninos santos' pela primeira vez em uma cerimônia com Dona Regina e Gonzala. A abuela Julieta diz que se lembra desse episódio. Incháustegui estava acompanhado por sua esposa, Cristina, que também participou do ritual. Dona Gonzala aparece nos registros do INI como uma das primeiras professoras bilíngues contratadas pelo Centro Regional INI Huautla. Ela foi responsável pela alfabetização de centenas de crianças Mazatecas. Abuela Dona Regina era uma curandeira, sua mãe era uma curandeira, sua abuela também era uma curandeira.

Quando Dona Julieta se casou com Lúcio, eles foram morar na casa ocupada por Dona Regina no centro. Ela se lembra da pobreza e das necessidades que aconteceram no início de seu casamento: "éramos pobres, meu filho Jorge - hoje com 66 anos - ia descalço para a escola quando tinha 5 anos, não tínhamos dinheiro para comprar sapatos". Quando tinha entre 20 e 25 anos, trabalhou como lavandeira. Seu marido trazia as roupas da polícia para ela lavar e passar. Julia Julieta Casimiro acordava lavando roupas no rio antes do sol raiar. $O$ marido às vezes comprava uma caixa de mangas e vendia na praça da cidade.

$\mathrm{Na}$ época dos hippies, Mama Julia bordava camisas para vender. O bordado é uma atividade tradicional Mazateca. A abuela Julieta 
inovou com os motivos, camisas com cogumelos, chegou a fazer algumas com a língua dos Rolling Stones. As bandas da Cidade do México encomendavam camisas bordadas com seu nome para usar em suas apresentações. Em sua época de maior atividade, possuía 30 bordadoras trabalhando na sala de estar da casa. Lembra-se de que bebiam cana enquanto conversavam e bordavam as camisas: "Ajudei a levantar muitas famílias em San Miguel com os bordados", lembra Dona Julieta.

Sua filha mais nova, agora com 44 anos, lembra-se de quando criança seus pais viajavam para Oaxaca ou Distrito Federal com camisas para vender na cidade. Essas viagens duravam de 10 a 15 dias, período em que ficavam sob os cuidados de sua irmã mais velha. Quando o negócio de vendas de roupas foi se consolidando, abriu uma pequena loja no centro para vender camisas e artesanato.

Os hippies chegaram a formar um acampamento em Puente de Hierro, a $11 \mathrm{~km}$ de Huautla. Mama Julia, como era conhecida na época, descia ao rio para vender camisas bordadas, mel e 'meninos santos'. Aos 30 anos, ela começou a realizar rituais com 'meninos santos' para os rapazes e abriu sua casa para alugar um quarto para turistas. Don Lucio tinha certas reservas quanto à abertura do conhecimento da linhagem para estrangeiros.

Em 1967, quando a presidência de Huatla foi exercida por Isauro Nava, começou a perseguição aos hippies na cidade. Paradoxalmente, Isauro Nava também era curandeiro e havia apresentado o ritual com 'meninos santos' a Gastón Guzmán em 1958, no Rancho de Cura. Começou um período de perseguição que se estendeu à presidência de Valeriano García Rojo (1972-1974). Em tempos de maior tensão, o governo mexicano implementou barreiras em Teotitlan para proibir a chegada de hippies, estrangeiros e mexicanos, em Huautla. Apesar dos postos de controle, os jovens mexicanos contratavam tropeiros para atravessar as montanhas (Feinberg 2003; García Cerqueda 2014).

Entre os que frequentavam a casa estavam os gringos e também alguns mexicanos que ainda a visitam. Uma de suas filhas diz que 
Santana esteve entre os ilustres visitantes: "Imagina, Santana tocando violão nesta escada”. Alguns dos meninos ainda visitam a abuela e dizem que a casa era de madeira, sustentada por paus, na encosta da montanha. Abuela comenta: "e não caiu". A abuela Julita lembra que no momento da repressão ela teve que fugir com uma bacia de cogumelos quando vieram avisá-la de que a polícia estava indo para sua casa. Com a repressão em Huautla, começaram os convites para realizar os rituais na Cidade do México, depois vieram os convites para realizá-los nos Estados Unidos.

Ao longo dos anos, a abuela Julieta passou a priorizar seu trabalho de xamã e seu lado espiritual. Com o aumento de seu prestígio, ela recebeu convites para realizar cerimônias no exterior, principalmente nos Estados Unidos e Europa. A abuela já trabalhou com Elisabeth Targ (1961-2002), psiquiatra pesquisadora sobre o papel da espiritualidade na cura.

Seu trânsito internacional se consolidou quando foi convidado a participar do Conselho Mundial das 13 Abuelas Indígenas, que reúne xamãs de várias partes do mundo em uma iniciativa global iniciada em 2004, em um Centro de Retiros no território da Confederação Iroquês, no estado de Nova York. A primeira reunião do Conselho foi realizada em 2005. A segunda reunião, em 2006, foi realizada em Huautla, na casa da abuela Julieta. Como participante do Conselho, ela visitou vários lugares: Estados Unidos, Brasil, Nepal, Japão e vários locais da Europa. A iniciativa do Conselho preocupa-se com a paz mundial, o equilíbrio ecológico e o respeito pelas culturas tradicionais, seus medicamentos e rituais (Schafer 2012). Os movimentos da Nova Era buscam o contato com os xamãs tradicionais como uma maneira de legitimar as práticas neo-xamânicas (Joralemon 1990).

Alcantara (2015) afirma que quando Wasson experimentou cogumelos com María Sabina, nasceu o neo-xamanismo. Os trabalhos de Wasson, Castaneda, Aldous Huxley abriram um novo horizonte para os jovens ocidentais que experimentavam drogas psicodélicas. De fato, a popularização da imagem de María Sabina provocou a chegada 
maciça de hippies em Huautla durante a década de 1960. Naquela época, Mama Julia era uma mulher de 30 anos que abriu o ritual para estrangeiros, um ritual que ela aprendeu com Dona Regina quando tinha 15 anos. Há 50 anos, a abuela Julieta realiza rituais em Huautla. Do seu jeito, abuela Julieta combina o conhecimento tradicional com sua projeção global.

A abuela Julieta é conhecida mundialmente e recebe um público variado. Seria difícil descrever a variedade de pessoas que participaram de rituais durante o período em que acompanhei o trabalho da abuela Julieta. Parte do público é de viajantes de lugares distantes, latino-americanos, norte-americanos, europeus, russos, japoneses; acompanhei até como tradutor o trabalho com um casal libanês e trabalhei com uma garota israelense. Há um público nacional, que também é heterogêneo. Varia de atores da rede de televisão, funcionários públicos do Ministério da Economia, jovens curiosos para experimentar e pessoas comuns que enfrentam problemas físicos ou existenciais. Há também os amigos da família, os jovens que frequentam a casa da abuela desde os anos 1970 e hoje se tornaram senhores sessentões. Às vezes chegam pacientes de outros estados, como Guerrero, Veracruz, Cidade do México, Guanajato, Puebla. Em uma ocasião, uma família Nahua chegou de uma região próxima da baixa Mazateca.

Esse público heterogêneo concorre com diversos propósitos. Há quem queira experimentar por curiosidade e há quem quer participar do ritual para abrir os caminhos na busca de equilibro; há quem chega com problemas existenciais e quem chega com problemas de saúde. Os rituais de cura têm algumas peculiaridades que serão abordadas mais adiante. Uma parte do público é composta por psiconautas da Nova Era que buscam experiências com plantas de poder. Grupos de daimistas, que participam do culto ao santo daime em vários países da América do Sul e México, não são incomuns. Há quem vem numa jornada mística e quem vem com perguntas acadêmicas. Em Huautla, conheci vários antropólogos e psicólogos de várias partes do mundo. Podemos dizer que o público que visita a abuela é cosmopolita. 
Existem diversos tipos de trabalhos durante o ritual. O papel principal do xamã é abrir os caminhos, guiar a viagem e ajudar, se necessário. As músicas são usadas para guiar a viagem. Em alguns casos, são canções reveladas pelos próprios 'meninos santos', em outras oportunidades utilizam músicas em mazateco. A abuela Julieta e sua família trabalham com louvores religiosos em mazateco. O ritmo é mais importante que a letra. Através das melodias, o xamã guia a viagem. Quando é hora de terminar o ritual, as melodias com o ritmo mais marcante são usadas para trazer os participantes de volta. Nos trabalhos para abrir os caminhos, a experiência tem um componente existencial.

Testemunhei vários rituais de cura: o gordo gritão; a ceguinha Nahua; o junkie americano; a esposa do Miguelito. Quando se trata de um ritual de cura, durante o transe, as várias partes do corpo são mencionadas e se pergunta aos 'meninos santos' se há alguma doença. Durante esse tipo de cerimônia, a medicina permite que o xamã 'enxergue' a doença no corpo do paciente. Voltarei a esse assunto quando aborde o 'olhar' como parte do meu aprendizado. Para pacientes que sofrem de um problema físico e estão em tratamento medicamentoso, solicita-se a suspensão do medicamento 24 horas antes, para que não haja interação com a medicina dos 'meninos santos'. Em alguns casos mais graves, a abuela recomendou que a pessoa se fortalecesse antes de realizar o trabalho. Testemunhei casos em que ela recomendou que a pessoa recorresse ao 'chupador', especialista em remover bruxaria do corpo sugando. Também testemunhe o trabalho de alguns 'chupadores'. Existem outros rituais para trabalhar o tona, que seria o animal de ascendência, e também rituais para o Nahual. Nahualismo é a transformação, transmutação em animal. Mais tarde, abordaremos essa experiência.

Se focarmos nossa atenção no público, ficaremos tentados a classificar os rituais da abuela Julieta como neo-xamanismo; mais, se focarmos na pessoa da abuela Julieta, encontraremos uma abuela Mazateca tradicional, nascida antes da abertura das estradas e da chegada das 
mudanças políticas. Pode-se dizer que a abuela realiza rituais tradicionais atualizados para um novo público, mais seria superficial. Todas as tradições são transformadas para permanecerem as mesmas.

Acredito que o caso da abuela Julieta seja relevante para discutir essa divisão entre xamanismo e neo-xamanismo. Como assinala Langdon (2013), a aplicação do neologismo tende a estigmatizar o xamanismo como se tratasse de um xamanismo não autêntico. Antropologicamente, devemos analisá-lo como várias performances do xamanismo. Durante a investigação, nos perguntamos em mais de uma ocasião sobre a intertextualidade dos rituais com 'meninos santos'. A antropologia tradicionalmente trabalhou os rituais ao interior de uma tradição cultural, mas, na prática, encontramos participantes de diferentes tradições, o que provoca intertextualidade. Os rituais podem ser interpretados a partir de uma multiplicidade de tradições, a experiência pode ser interpretada a partir do encontro de diversas tradições. A participação nos rituais é uma participação expectante e essas expectativas tem como pano de fundo a tradição cultural do participante, suas crenças, seus valores.

A proposta de Langdon (2016) de analisar o xamanismo como um modo performativo tem implicações analíticas relacionadas ao conceito de performances trabalhadas por Bauman (1975; Bauman \& Briggs 2015). Primeiro, enxergar o xamanismo a partir das performances, implica levar em consideração o desempenho do xamã e do público participante. A performance vai estar marcada em um espaço entre keyings marcadores do início e do final daperformance. No caso das performances analisadas: um marcador inicial (defumação, orações e invocações), um período liminar e um marcador de fechamento (neste caso, fechar o corpo, protege-lo com San Pedro). Diferentemente das cerimônias rigidamente estruturadas, durante a performance do xamanismo, há um certo grau de improvisação, decorrente da interação do xamã com o público. As expectativas do público podem variar, desde o público da new age até pacientes que procuram a sanação. $\mathrm{O}$ xamã deve ter a competência de orientar o trabalho durante o período liminar. 
Analisar o xamanismo como um modo performático implica vê-lo como produto do encontro da experiência com a participação expectante do público participante. Este ponto é relevante por várias razões. Por um lado, evita a postura romântica relacionada à valorização do 'autêntico' em oposição a fenômenos supostamente adjetivados com o prefixo 'neo', como a categoria de 'neo-xamanismo' usada por vários autores. Na base desta posição está a suposição de que o xamanismo 'autêntico' funciona dentro de uma tradição cultural, o que é explicitado em Lévi-Strauss (1967). Ao analisar a cura xamânica, o autor atribui a eficácia simbólica do ritual a que: o paciente acredita no que o xamã está fazendo; o feiticeiro acredita em sua performance; e o público (que participa da mesma tradição cultural) também acredita na eficácia do trabalho. Essa análise unidimensional não explicaria performances xamânicas das quais participam pessoas pertencentes a diferentes tradições culturais. Muitas vezes, as performances xamânicas transcendem as fronteiras de uma tradição cultural, como os casos analisados em Taussig (1987), Langdon (2016).

\section{Rituais com 'meninos santos'}

Em uma conversa junto ao fogão, Omar, filho da abuela, comentou: "Castaneda está tudo errado". Essa frase ficou girando na minha cabeça. As partes mais memoráveis de seus livros são as anotações de suas experiências com várias plantas: peiote, datura, cogumelos. Um de seus personagens é um feiticeiro mazateco, Don Genaro. Apesar dessa informação, notei que Castaneda não descreveu os rituais, ele não penetrou na cosmologia do grupo.

'Meninos santos' é o que os mazatecas chamam chan jtsi, as diferentes espécies de cogumelos usados nos rituais: ndi kixo, os cogumelos das terras caidas; ndi ndajai, cogumelos do bagaço da cana; ndi nisé, conhecido como passarinhos; ndi rraja, também chamado de San Isidro.

Os mazatecas podem realizar o consumo ritual dos 'meninos santos' junto a um xamã ou podem fazê-lo em casa, em frente ao altar 
doméstico. A importância do xamã é porque é ele quem 'abre os caminhos', quem sabe agir em caso de imprevistos na viagem, quem interpela, mas, sobretudo, quem orienta. Rituais com 'meninos santos' podem ser rituais de cura, física e espiritual. Alguns participam de rituais para tratar de doenças físicas, outros para resolver problemas existenciais. Há quem realize o ritual para ver o que está acontecendo e resolva tensões sociais, outros procuram o ritual para abrir caminhos espirituais.

Realizei vários rituais com diferentes xamãs de Huautla. Minha primeira limpeza foi com Dona Antônia, no bairro do INI; realizei três rituais de pedimento, com o professor Alfonso. Meu primeiro ritual com 'meninos santos' foi com a abuela Julieta, mas também trabalhei com Dona Inês, com a esposa de Prócoro e com vários filhos da abuela. Em várias ocasiões, fui assistente da abuela Julieta. Finalmente, também realizei cerimônias frente ao altar que construí no meu quarto.

Ao analisar comparativamente as diferentes experiências, observei, por um lado, uma grande diversidade de performances, de estilos diferentes, enquadradas por um ritual de abertura e um ritual de encerramento. No período liminar entre esses marcadores rituais, o xamã guia a viagem, consegue enxergar as imagens dentro do outro, é uma experiência intersubjetiva que envolve imagens não visuais (veja também Perez Quijada 1996).

Ao entrar no recinto onde o ritual vai ser realizado, os participantes recebem uma limpa. Estas limpas são feitas com plantas aromáticas, podem ser louro, alecrim e têm o propósito de limpar é jogar os 'maus ares'. Depois de limpar o corpo com os galhos, as pessoas são banhadas pela fumaça do copal, que limpa e comunica. As pessoas são então colocadas em colchonetes no chão em frente ao altar.

O altar, frente ao qual a cerimônia é realizada, está colocando na parede leste, o nascente. O posicionamento geográfico é importante. Nos rituais de abertura, o xamã é posicionado invocando os cinco pontos cardeais. Os pontos cardeais são representados por uma cruz, Leste, Oeste, Norte, Sul. "O que acontece se colocarmos a cruz em 
pé?", observa Omar. O quinto ponto cardinal, aquele que se conecta com o supramundo e o inframundo, que é representado no altar como símbolo.

O altar é basicamente uma mesa. Para os mazatecos, assim como para outros grupos indígenas mexicanos, a terra é como uma mesa. Os vários níveis do supramundo são como mesas diferentes: mesa de leite, mesa de flores etc., que levam a Do Asean, onde está o pai eterno, sentado ao lado de uma mesa de prata na qual dança um peru. Incháustegui (1994) aponta que essa é uma representação pré-hispânica e que é diferente da ideia de Deus. O outro polo desse eixo é o inframundo, composto por sete degraus, que os mortos percorrem até chegar no mundo dos mortos. Para os mazatecos, os mortos não vão ao céu como na cosmovisão católica, eles vão para o inframundo, para o mundo dos donos do lugar, os chikones. Para os mazatecos, como Barabas (2006) observa, o altar é um portal que permite o trânsito entre o inframundo e o supramundo.

O altar é o símbolo dominante e representa o portal que conecta com o supramundo e o inframundo. Este símbolo dominante suporta outros símbolos diversos, como imagens de santos, flores, velas, grãos de cacau, água fresca, jna jno (piciete), também chamado de San Pedro. Ao lado do altar, o copalero, a fumaça do copal limpa e serve como um canal de comunicação. As imagens dos santos correspondem às entidades do supramundo. Bartolomé \& Barabas (2013) observaram que as tradições pré-hispânicas no México tinham suas entidades mais importantes ligadas ao inframundo, como os donos do lugar. Os santos católicos foram incorporados de forma sincrética como entidades do supramundo. Durante o ritual de abertura, os santos católicos são invocados, como entidades do supramundo e depois os donos do lugar, a partir da toponímia sagrada: Cerro da Adoração, Cerro Rabón, entre outros. Aqueles que vão participar do ritual são reportados. Se pede uma boa viagem e um bom retorno (Carrera Gonzales \& van Doesburg 1992; Manrique Rosado 2010, 2013). 
O período entre a ingestão e os primeiros efeitos dos 'meninos santos' é de aproximadamente 50 minutos. A abuela Julieta, uma mulher de profunda fé, costuma rezar o rosário durante esse período. Com seu devocionário mazateco, ela reza o rosário e, nos louvores, pede pela alma dos mortos da família; santos católicos e chikones são invocados; se pede uma boa viagem para os participantes do ritual.

Os participantes são acomodados em um colchonete e agasalhados com um cobertor. Quando a medicina começa a fazer efeito baixa a temperatura corporal, se sente uma alteração na percepção e se entra num estado liminar, um estado semelhante ao sonho, no qual a alma se desprende do corpo. Realizei o ritual de 'meninos santos' com vários xamãs tentando perceber um padrão performativo do ritual durante esse período liminar. Aprendi que cada guia tem um estilo particular de comandar a viagem: canções em Mazateco, orações, diálogos com as entidades, danças.

Mas que focar no público, como antropólogos, focamos na forma de relacionamento, algo que poderíamos indicar como ética da bruxaria, ou como os xamãs entendem o bom viver. Esse relacionamento envolve valores como reciprocidade, responsabilidade, caridade. Esses valores orientam as relações com o público, com outros feiticeiros e com entidades extraordinárias.

O xamanismo envolve uma troca, então você precisa ter uma retribuição, seja na forma de pagamento em dinheiro, em algum objeto ou até em comida. Omar, o filho mais novo da abuela Julieta, também trabalha com xamanismo. Seu público é variado. Inclui trabalhos para mazatecos, como limpas, rituais para a construção de um novo lar, leitura de milho, comunicação com os mortos, rituais com 'meninos santos', temazcal. Ele também tem seu público nacional e internacional. Em mais de uma ocasião, a abuela comentou comigo: "Se você quer ser um xamã, precisa viver do xamanismo". A abuela Julieta, assim como outros xamãs de Huautla, cobra um preço pelas cerimônias, é um valor de referência, aberto à negociação e pode variar de acordo com o tipo de trabalho. 
No meu caso, paguei o ritual nas primeiras oportunidades, depois nosso intercâmbio mudou quando me tornei o fotógrafo da abuela. Todas as manhãs, por volta das 10 horas, comprava alguns pães e ia a tomar café na casa da abuela Julieta. Nas conversas ao pé do fogão, comentamos o que enxergamos durante o ritual da noite anterior. Algumas partes, as mais delicadas, eram faladas em voz baixa. Abuela ouvia atentamente minhas histórias e me dava conselhos sobre como proceder. Parecia uma sessão de controle daqueles realizados por psicanalistas, ou reuniões de orientação, com seu conteúdo catártico. As conversas com a abuela eram verdadeiras aulas sobre hermenêutica Mazateca. Discutimos o que aconteceu nos rituais, conversamos sobre os vários símbolos da tradição mazateca, ela me falou sobre a família ou sobre as diferentes plantas de poder com as quais ela sabe trabalhar: 'meninos santos'; salvia divinórium, também conhecida como pastora; peiote; sementes da virgem.

As sessões com os 'meninos santos' são feitas a partir das demandas, não têm um dia específico. Às vezes a abuela estava exausta, com cerimônias quase diariamente. Insistimos em que ela descanse, mas se alguém viesse pedir um ritual de cura, ela se disponibilizaria, apesar do cansaço: "pobres crianças, elas vêm de tão longe e estão necessitadas. Você não pode negar ajuda aos necessitados”. Essa atitude caritativa também se repete com os vendedores que passam a tarde na casa, para vender flores, alimentos, legumes. $\mathrm{O}$ mesmo acontece com as mulheres que bordam roupas para vender.

O ritual com 'meninos santos' não resolve todos os problemas. Em alguns casos, a abuela encaminha para outros xamãs para tratar problemas mais complicados. Como ela observou, os feiticeiros se ajudam: "Às vezes, quando tenho um caso difícil, peço ajuda a outro xamã com quem trabalho. Existem alguns pacientes que estão muito doentes e eu os encaminho para serem tratados primeiro pelo chupador."

Os chupadores são outra prática de xamanismo na mazateca. A técnica de extrair objetos por sucção é amplamente disseminada no xamanismo tradicional americano. Acompanhei a abuela Julieta em 
sua visita ao chupador. Levamos também uma moça que estava sendo tratada na casa, a esposa de Miguelito. Em uma sala mal iluminada, diante de um altar com vestígios de centenas de velas, copos com água, ovos e imagens de santos, o chupador realizava sua performance. Depois de sugar o corpo da jovem, ele tirou três pedras da cabeça. As pedras estavam secas e quentes, por isso dificilmente saíram de sua boca. Quando chegou a hora da abuela, chupou algumas pontas de pimenta seca. A abuela me disse que ele já tinha tirado ossos de galinha, unhas, velas de morto.

Uma vez falamos dos bruxos tje'e os que praticam o mal. A conversa surgiu a partir de algumas fotos que eu registrei com ofertas invertidas no nindon Tokoxo. Eles colocaram velas de cabeça para baixo, para que não pudessem ser acesas, grãos de cacau em sacolas de plástico, para que não pudessem ser absorvidos pelos donos do lugar e para completar o anti-ritual, os excrementos de animais acima das oferendas. Uma das maneiras de executar o trabalho é fazer um pedido em nome da vítima e fazer as ofertas invertidas como uma maneira de despertar a raiva dos donos do lugar, os chikones. "Há pessoas que pagam muito por esse tipo de trabalho, mas há poucos feiticeiros que se atrevem a fazê-lo, porque, a longo prazo, as entidades acabam descobrindo e os males retornam ao feiticeiro". Em uma ocasião em que brincávamos sobre o assunto, a abuela ficou séria: "em minha casa nada de magia negra, apenas magia branca”, como forma de indicar o equilíbrio de espírito necessário para realizar o trabalho com os 'meninos santos' (sobre os tje'e ver também Manrique Rosado 2013a).

\section{Uma etnografia da experiência xamânica}

Ao refletir sobre o trabalho de campo, Cardoso de Oliveira (1988) trabalhou o conceito de fusão de horizontes da comunicação, baseado em Gadamer (1992, 1993) e Habermas (1989). Na lógica da ação comunicativa de Habermas (1989), a comunicação ocorre no plano discursivo. Roberto Cardoso de Oliveira costumava dizer 
que esses modelos ideais eram importantes porque, quando contrastados com a realidade, 'revelam', quase no sentido fotográfico - quando os filmes eram revelados a partir dos negativos - aspectos da realidade que não se enquadram no arquétipo.

No caso de rituais com 'meninos santos', a comunicação não ocorre apenas no nível do discurso; há uma comunicação que ocorre no plano de imagens não ópticas, imagens mentais. Outro aspecto importante é que as 'viagens' não são uma alucinação individual, há uma intersubjetividade que opera no plano dessa comunicação com imagens mentais. $\mathrm{O}$ xamã pode enxergar dentro do outro, pode ver a viagem, pode ver o nahual, pode ver e se comunicar com os donos do lugar. A experiência de campo envolveu o aprendizado sobre uma forma de comunicação intersubjetiva, se deu no nível da experiência e não simplesmente no nível do discurso.

Essa etnografia nos confronta com novos problemas teóricos. Embora a experiência com 'meninos santos' tenha uma dimensão subjetiva, ela adquire uma dimensão intersubjetiva durante o ritual, quando o xamã consegue 'enxergar' enquanto trabalha com seus pacientes. Essa experiência é objetivada no nível do discurso, através dos relatos, no meu caso, quando discutia com a abuela na manhã seguinte ao ritual. Essa dimensão intersubjetiva também é objetivada no diálogo com outros mazatecos. Quando narrava a experiência, os mazatecos mostraram que ela era consistente em termos de sua tradição cultural, o que colocava em evidencia a competência comunicacional, um elemento importante na análise das performances (Bauman 1975; Langdon 2006).

Como antropólogo, minha expectativa não era o turismo místico, minha intenção era trabalhar com os 'meninos santos' em uma experiência prolongada. Não bastava experimentar uma vez, é preciso conhecer e se deixar conhecer. $\mathrm{O}$ aprendizado foi gradual e a continuação apresento os principais pontos desse processo. $\mathrm{O}$ material trabalhado não é o relato de 'viagens individuais', são o relato de experiências que foram discutidas com várias pessoas durante o trabalho de campo e se encaixam no que os mazatecas esperam delas. Embora 
trabalhemos com imagens mentais, a visualidade dessas experiências também pode ser explorada através da arte mazateca. Várias representações ilustram os murais da cidade, na presidência, no centro da praça e em várias paredes de Huautla. Os mesmos estão inspirados nas experiências com 'meninos santos' e foram realizados por um grupo de artistas mazatecos.

Um dia, tomando uma cerveja em um bar com Jorge (66 anos), o primeiro filho da abuela, estávamos discutindo xamanismo. Contei a ele sobre minhas hipóteses de pesquisa: - "Os antropólogos costumam trabalhar o xamanismo como relacionado às técnicas de êxtase de Mircea Eliade inspirado no xamanismo siberiano. Em América o xamanismo também está relacionado ao poder político." Ele me ouviu atentamente e ponderou: - "O êxtase é quando bebemos cerveja. Ser xamã é poder enxergar" - ele abaixa a cabeça levemente e o olhar penetrante desafia meus olhos. "Ser um xamã é enxergar dentro do outro".

Uma das coisas mais interessantes sobre esse processo foi aprender a 'enxergar'. A primeira vez foi no caso do gordo gritão. Naquele dia, fui ajudar à abuela durante o ritual. Ela me colocou em um lugar diferente na sala, me deixou do lado do altar. Depois, conversando com Omar, ele me disse que esse era um local importante para manter o equilíbrio do templo. Naquele dia, umas garotas italianas e a família de Guerrero (Mx.) participaram do ritual. Esta família era composta por um casal mais velho, com mais de 65 anos, e seu filho, com cerca de 35 anos. Uma família muito formal que procurou o ritual de cura porque o homem sofre de diabetes. A abuela perguntou se ele havia seguido a orientação de interromper o medicamento 24 horas antes. Começamos o ritual e o homem estava visivelmente nervoso. Quando a abuela estava citando as diferentes partes do corpo, citando o fígado, 'eu enxergue' uma coisa diferente. Parecia uma bola de luz, que durante todo o ritual a abuela trabalhou e apertou para diminuir de tamanho. Naquele dia, consegui 'ver' a doença no gordo gritão. Naquele dia, no final da cerimônia, a abuela perguntou à família e às italianas que cores tinham visto no início do trabalho: um grupo 
respondeu branco e o outro azul. Eu tinha visto azul e branco. Esses fatos foram discutidos mais tarde na manhã seguinte com a abuela.

Após a procissão de Corpus Christi, em 24 de maio, estávamos na casa da abuela. Naquele dia não haveria cerimônia e abuela aproveitaria a oportunidade para descansar. Quando eu estava quase indo embora, chegou uma humilde família de indígenas nahuas, do estado de Veracruz. Eles trouxeram uma mulher cega acompanhada pela filha de aproximadamente treze ou catorze. A mulher disse que perdeu a visão um mês após a morte do marido. Eles viajaram centenas de quilômetros para consultar a abuela. A abuela, apesar do cansaço, concordou em fazer essa cerimônia, por caridade. Naquele dia, Coyotita e eu trabalharíamos com a abuela Julieta. Ela me apresentou como filho adotivo, que daria apoio à realização do ritual com sua última filha.

Naquele dia acompanhei o trabalho sem ter ingerido os 'meninos santos', apesar disso, meus olhos arderam como se eu tivesse consumido. Após o início da cerimônia em que a abuela Julieta abriu os caminhos, sua filha trabalhou com a ceguinha. Ela a colocou na frente do altar e segurou a cabeça. Da minha posição de guardiã do altar pude ver duas bolas de luz na cabeça da ceguinha nahua e observar como a irmãzinha trabalhava nelas. A mulher cega disse que seu marido tinha sido morto assassinado, quem disparou foi o irmão do delegado da polícia local. Coyotita a ajoelha e mexe na bola de luz que eu estava vendo. A garota, filha da ceguinha permaneceu em silêncio durante toda a cerimônia. No final da abuela perguntou sobre as imagens durante a viagem, a menina diz que viu seu avô morto, que também morreu assassinado. Após a cerimônia, a abuela recomenda que a mulher cega consulte um chupador. Eu não tive dúvida de que a cegueira era traumática, um diagnóstico compartilhado por Coyotita e pela abuela.

Quando a abuela me colocou como guardião durante o ritual, comecei a ver a viagem dos outros participantes, a ver doenças como bolas que se acendem na parte do corpo afetada, a cuidar de que os participantes tiveram uma boa viagem e enxergar a quem precisava de 
mais do que uma sessão para resolver seus problemas. Perez Quijada (1996) também relata uma experiência intersubjetiva semelhante ao apresentar os resultados de seu trabalho de campo com xamanismo na baixa Mazateca.

Outro passo do aprendizado foi quando os mortos da família apareceram para mim. Primeiro, se me apresentou a abuela Regina, que foi quem iniciou à abuela Julieta; depois, em algumas oportunidades se apresentou Don Lucio, falecido marido de Dona Julieta e filho de Dona Regina. Dona Regina apareceu cercada por "meninos santos", Dom Lucio apareceu transfigurado em onça. Existe uma relação entre os mortos da linhagem e o ritual com os 'meninos santos'. Alguns murais da cidade ilustram esse relacionamento. Para os chjota-chjine, a viagem ocorre no eixo que liga o supramundo ao inframundo, o mundo dos mortos. A presença dos mortos da linhagem era um índice do meu progresso no caminho do conhecimento.

Durante os trabalhos, também apareceram os donos do lugar. No meu caso, essa experiência foi atravessada pelo nahualismo. Quando os donos do lugar aparecem é preciso conversar com as entidades. É como tentar falar durante um sonho em que experimentamos o encontro com essas entidades extraordinárias. Do diálogo depende a interação, a concessão de dadivas e poderes. Na primeira vez em que um dono do lugar se me apresentou, comentei com um cogumelero, filho de uma chjota-chjine que também trabalha com 'meninos santos'. Ele enfaticamente me aconselhou: "Você precisa conversar com eles, pedir-lhes dádivas".

O nahualismo, envolve a transmutação em animal. Durante as experiências, me tornei uma onça em um par de oportunidades e finalmente me transmutei em águia. Nesses casos, deve-se acrescentar que eu pude sentir a transformação, mas não pude me ver como o animal, quem me descreveu o animal foram os xamãs que trabalhavam comigo.

A primeira vez que me tornei uma onça, foi depois de viajar pelas mesas do supramundo e chegar ao o pai eterno e seu peru, foi 
ele quem me concedeu o poder de transformação. Transformado em onça, vi meus inimigos como um bando de cães latindo ao meu redor. Como onça, dei um golpe que feriu alguns cães. Quando contei o episódio para a abuela Julieta, preocupado, ela me perguntou com simplicidade e brilho nos olhos: - "Você não mordeu a cabeça deles?" Entendi que essa experiência se encaixava na gramática da tradição mazateca. Então ela comentou: "os meninos santos estão ensinando você. Não sei por que, mas eles estão te ensinando. Deve ser porque você não é gringo". Os 'meninos santos' têm agência, são eles que nos revelam coisas, mas as revelações precisam ser confirmadas pelo xamã e pelos sonhos.

Tornei-me onça em outra ocasião, durante uma cerimônia realizada no santuário da abuela, dirigida por Omar, seu último filho. Naquele dia, estava localizado no lugar de guardião do templo. Meu papel naquela cerimônia de iniciação foi controlar as fronteiras daquele espaço sagrado: "nada entra, nada sai". Durante a cerimônia, uma das participantes ficou especialmente perturbada, gritou, chorou. Vi os problemas passarem como se fossem bolinhas, que como onça mastiguei e desintegrei. A certa altura, apareceu uma cobra. Lembrando do conselho de abuela, mordi a cabeça dela. Após a cerimônia, converso com os participantes e conto o que tinha visto. A menina, já mais calma, confirma que as cobras saíram dela. Ela ainda se sentia um pouco angustiada. Naquele dia, durante a viagem, Don Lucio se me apresentou como onça e me convidou para andar no nindon Tokoxo, a montanha do Chikon Tokoxo. Quando contei esse episódio a Omar, após a cerimônia, ele confirmou que me enxergou como uma onça, o mesmo nahual de seu pai, Don Lucio.

A festa de San Pedro no calendário católico, também marca um período em que é aberta a passagem entre o inframundo, o supramundo, e o mundo dos vivos. Nesta data, os chjota-chjines podem pedir poderes aos donos do lugar. Quando trabalhei nesse período, vi muitos espíritos alegres, dançando como se fossem huehuentones, eram centenas de ancestrais dançando, comemorando a abertura da passagem 
que separa o reino dos mortos, aberta por um benevolente San Pedro. Naquele dia eu me tornei uma águia, voei de Huautla para o Brasil. Senti a leveza do voo da águia, sua visão e seu sentido do olfato, mas não pude ver as características do nahual. Mais tarde, trabalhei meu nahual com Coyotita. Mais uma vez eu me tornei uma águia, ela podia me 'enxergar', eu era uma enorme águia de prata. Senti as asas e passei boa parte da cerimônia sentado. Naquele dia, os donos do lugar me entregaram um bastão e eu dei por finalizadas minhas experiências.

Uma das coisas mais impressionantes para mim foi a experiência do nahualismo. Quando me tornei onça pela primeira vez, fiquei um pouco confuso. Para minha surpresa, quando contei sobre a transformação aos meus interlocutores mazatecos, eles viram isso como natural. Renato, do INI, comentou que era assim mesmo, uno se transforma em animal. Coyotita observou que existem 12 animais, mais que um deve trabalhar o seu nahual. $\mathrm{O}$ professor Alfonso me disse que, se eu quisesse continuar desenvolvendo meu nahual, deveria fazer um boneco do animal para trabalhar com ele nos rituais.

\section{Xamanismo como modo de performático e fusão de horizontes de comunicação}

Com o passar dos meses, meu relacionamento com a família da abuela Julieta se tornou cada vez mais próxima. Todas as manhãs eu descia do bairro de La Cruz, passava pelo mercado, comprava seis pães e seguia para a casa da abuela Julieta para beber um café de panela e conversar. Eu acompanhava a abuela nas várias mayordomias que entrelaçam o tecido social. Gabriel estava sempre disposto a acompanhar a abuela, a ouvir as histórias dela, eu me preocupava com a sua comida.

"Todo mundo já sabe que você é o guardião da abuela", brincou uma de suas filhas. Eu, que era o companheiro habitual de abuela, não dei muita importância a primeira vez. $\bigcirc$ tema do guardião da abuela começou a aparecer várias vezes nas conversas ao redor do fogão. Um dia, conversando com o marido de uma das filhas, perguntei o que 
era aquele 'guardião'. "Guardião é um tipo de xamã, poderoso, que se torna um animal", respondeu ele.

Confesso que naquele dia comecei a me preocupar. Teria passado o limite? Qual é o limite da fusão dos horizontes da comunicação? As conversas no fogão começaram a adquirir outras conotações. Uma das filhas da abuela me perguntou: "Por que você quer aprender? Você quer abrir um templo para ganhar dinheiro?". Uma e outra vez respondo que não, que como antropólogo tenho que conhecer pela experiência própria para traduzir para um público mais amplo. Outra das filhas me provocou: "Você não pode levar a magia de Huautla para outro lugar. Porque não arranjas uma esposa e ficas em Huautla." De uma maneira ou de outra, essas piadas indicavam o limite do meu aprendizado. Como antropólogo, não posso, nem devo, me tornar um xamã.

Quando me despedi, uma das filhas me disse emocionada: "Gabriel, você não está levando nada, apenas aperfeiçoou o que trouxe das suas experiências. Você é uma pessoa sábia e não é por causa do que aprendeu nos livros". Omar, com quem eu fiz vários trabalhos, me diz: "Irmãozinho, no começo eu te vi como muito racional, no entanto, você conseguiu se transformar em onça e se transmutar em águia. Você conseguiu”. Nesse ponto, penso no paralelismo existente entre a viagem xamânica e o trabalho de campo como imersões em mundos extraordinários que devemos traduzir.

$\mathrm{Na}$ primeira parte do trabalho, discutimos a categoria de xamanismo, sua caracterização para o caso mesoamericano e contextualizamos o caso do xamanismo contemporâneo em Huautla. Passamos do xamanismo como categoria, para conceituá-lo analiticamente como modo de performático (Langdon 2013). Na segunda parte do trabalho, focamos em um caso exemplar, a abuela Julieta Casimiro, que permitiu contextualizar historicamente a prática do xamanismo em Huautla, indicamos certos aspectos do ritual e da cosmologia para entender a prática do xamanismo contemporâneo, seu público e diversidade de práticas e especialidades. Trabalhar o xamanismo como um modo performático nos permite entender sua eficácia em con- 
textos tradicionais e cosmopolitas. A terceira parte é epistemologicamente mais complexa. Por um lado, reflete a experiência etnográfica da participação em rituais com 'meninos santos'. Essa parte centrada nos aspectos liminares do ritual pode parecer subjetiva. No entanto, é intersubjetivo, uma vez que essas experiências rituais foram discutidas com a abuela Julieta e outros interlocutores mazatecas. Em outras palavras, a descrição da experiência se encaixa no que os mazatecas esperam de uma experiência com 'meninos santos'. Peirano (2001) chama a atenção para a diferença entre o dito e o feito no campo da análise ritual. Construímos etnografia, não a partir de relatos de terceiros e sim a partir da experiência.

O texto reflete a experiência do êxtase xamânico vivido durante os rituais, a interação com seres extraordinários em um plano de transe onírico, a transformação em nahual e a obtenção de dons. Podemos afirmar que, tanto se encaixa com o que os mazatecas esperam da experiência, bem como também na caracterização realizada por Bartolome \& Barabas (2013:36) sobre o xamanismo tradicional no México.

Trabalhar o xamanismo como modo performático nos leva a desafiar teoricamente o conceito de fusão dos horizontes da comunicação (Cardoso de Oliveira 1998). Esse conceito trabalhado na antropologia por Cardoso de Oliveira (1998) é inspirado em Gadamer (1993) e Habermas (1989). Embora Gadamer dê importância teórica aos momentos não metódicos do conhecimento, que incluem arte, religião, dimensão emocional, o conceito adquire um aspecto discursivo em Habermas (1989), com o pressuposto de uma comunicação 'racional'. Cardoso de Oliveira (1998) aponta a importância do trabalho de campo para essa fusão de horizontes da comunicação e indica que a empatia também é uma forma de conhecimento. Ao analisar o xamanismo como um modo performático, devemos prestar atenção a cinco características das performances, indicadas por Langdon (2006): a experiência em relevo; participação expectante; experiência multissensorial; envolvimento corporal, sensorial e emocional; significado emergente. 
Trabalhamos o ritual como um poderoso aparelho comunicacional multimídia que envolve não apenas discursos, mas também cheiros como o do copal; canções, com seus ritmos; a iluminação do local; estados de consciência produzidos por 'meninos santos' e um tipo particular de intersubjetividade, que envolve participantes e seres extraordinários, como os donos do lugar. Passamos assim do plano da discussão racional para o nível da performance; da palavra e discurso para aos objetos símbolos, empatia e emoções; da ideia de um ego racional (ocidental), para outras formas de consciência intersubjetiva. Os rituais são um poderoso aparelho comunicacional, como observado pela tradição britânica (Radcliffe Brown; Leach), e esse aparelho opera por meio de performance, o que cria horizontes de comunicação intersubjetivos que transcendem, em muito, o plano discursivo do discurso racional. Estou me referindo ao que Langdon (2006, 2013) aponta quando indica que a performance cria momentos em que a experiência está 'em relevo', uma intersubjetividade emergente típica das performances, que implica envolvimento corporal, sensorial, emocional e intersubjetivo. $\mathrm{O}$ xamanismo contemporâneo não se opõe ao xamanismo tradicional. $O$ significado não está pré-estabelecido pela liturgia, mas é o produto da performance; um significado emergente que é produto da interação e da participação expectante, seja do público tradicional ou não tradicional que participa da experiência. Pensar no xamanismo como um modo performático nos permite compreender o xamanismo para além dos limites de uma tradição cultural, pensar no fenômeno em sua intertextualidade, que entrelaça várias tradições culturais tradicionais e contemporâneas.

\section{Referências:}

ATKINSON, Jane M. 1992. "Shamanisms today". Annual Review of Anthropology, 21:307-330.

BARABAS, Alicia. 2006. Dones, dueños y santos. Ensayo sobre religiones en Oaxaca. México: CONACULTA-INAH. 
BARABAS, A. \& BARTOLOMÉ, M. (eds.). 1999. Configuraciones éticas en Oaxaca. Perspectivas etnográficas para las autonomías. México: INAH/INI.

BARTOLOME, M. \& BARABAS, A. (eds.). 2013. Los sueños y los dias, xamanismo y nahualismo en el México actual". México: INAH.

BAUMAN, Richard. 1975. "Verbal Art as Performance". American Anthropology, 77(2):290-311.

BAUMAN, R. \& BRIGGS, C. 2006. "Poética e Performace como perspectiva crítica sobre a Linguagem e a vida social”. Ilha, Revista de Antropologia, $8(2): 185-229$.

CARDOSO DE OLIVEIRA, Roberto. 1988. Sobre o pensamento antropológico. Rio de Janeiro/ Brasília: Tempo Brasileiro/ CNPq. . 1998. O trabalho do antropólogo. São Paulo/ Brasília: Editora Unesp/ Paralelo 15.

CARDOSO DE OLIVEIRA, R. \& OLIVEIRA, L. R. 1996. Ensaios Antropológicos sobre Moral e Ética. Rio de Janeiro: Biblioteca Tempo Universitário.

CARRERA GONZALEZ, F. \& DOESBURG. S. 1992. Chan-chaon-yoma, el calendario agrícola Mazateco. Huautla: mimeo.

CASTANEDA, Carlos. [1968] 2001. Las enseñanzas de Don Juan: una forma yaqui de conocimiento. México: FCE.

CERQUEDA GARCÍA, Maximiliano. 2003. Efemérides de la mazateca alta. Oaxaca: Fondo Editorial IEEPO.

DEMANGET, Magali. 2000. "El precio de la tradición. En torno a los intercambios entre riqueza económica y espiritual en la comunidad mazateca de Huautla de Jimenez, Oaxaca". Cuadernos de trabajo, 6:9-57.

DUBOIS. 2011. "Trends in contemporary research on shamanism”. Numen, 58(1):100-128.

DURKHEIM, E. 1989. As formas elementares da vida religiosa. São Paulo: Ed. Paulinas.

ELIADE, Mircea. 1976. El chamanismo y las técnicas arcaicas del éxtasis. México DF: Fondo de Cultura Económica.

FEINBERG, Benjamin. 2003. The devil's book of culture. History, mushrooms and caves in southern Mexico. Austin: University of Texas Press.

. 2006. “I Was There' Competing Indigenous Imaginaries of the past and the future in Oaxaca's Sierra Mazateca”. Journal of Latin American Anthropology, 11(1):109-137.

GADAMER, Hans-Georg. 1992. Verdad y Método II. Salamanca: Ediciones Sígueme. 1993. Verdad y Método. Salamanca: Ediciones Sígueme.

GARCIA CERQUEDA, Osiris. 2014. Huautla, tierra de magia, de hongos... y de hippies. 1960-1975. Puebla: Benemérita Universidad Autónoma de Puebla.

GARCÍA DORANTES, Renato. 1996. Chan chaon Kjoatsjoale naxinándá yoma. Calendário agrícola, ritual y festivo de los mazatecos. México: INI. 
HABERMAS, Jürgen. 1989. Consciência Moral e Agir Comunicativo. Rio de Janeiro: Edições Tempo Brasileiro.

INCHÁUSTEGUI, Carlos. 1977. Relatos del mundo mágico mazateco. México DF: INAH. .1994. La mesa de Plata. Cosmología y curandeirismo en la Mazateca de Oaxaca. Oaxaca: IOC. 2000. "Entorno enemigo. Los mazatecos y sus sobrenaturales". Desacatos, 5:131-146.

JORALEMON, Donald. 1990. "The selling of the shaman and the problem of informant legitimacy". Journal of Anthropological Research, 46(2):105-118.

LANGDON, Esther J. 1992. "Shamanism and Anthropology". In LANGDON, J. \& BAER, G. (eds.): Portals of Power. Shamanism in South America, pp. 1-21. Albuquerque: University of New Mexico Press.

. 2006. "Performance e sua diversidade como Paradigma Analítico: a contribuição da abordagem de Bauman e Briggs”. Ilha, Revista de Antropologia, 8(1):162-183.

. 2007. "Shaman and shamanisms: reflections on anthropological dilemmas of modernity". Vibrant, 4(2):27-48.

. 2009. "Xamãs e xamanismo: reflexões autobiográficas e intertextuais sobre a antropologia". Ilha, Revista de Antropologia, 11(2):161-191.

. 2013. "New perspectives of shamanism in Brazil. Shamanism and neoshamanism as dialogical categories". Civilizations, 61(2):19-35.

2016. "The performance of diversity: shamanism as a performative mode". GIS, 1(1):9-39.

LEVÍ-STRAUSS, Claude. 1967. Antropologia estrutural. Rio de Janeiro: Tempo Brasileiro.

MAUSS, Marcel. 2003. Sociologia e Antropologia. São Paulo: Cosac \& Naify.

MANRIQUE ROSADO, Lidia. 2010. "Cosmovisión y geografía sagrada Mazateca”. In BARABAS. A. \& BARTOLOMÉ, M (eds.): Dinámicas culturales, religión y migración en Oaxaca, pp. 302-332. México: INAH.

2013. "Porque también somos espíritus. Entidades anímicas y sus enfermedades entre los mazatecos”. In BARTOLOMÉ, M. \& BARABAS, A. (eds.): Los sueños y los días, chamanismo y nahualismo en el México actual, pp. 93-121. México: INAH.

. 2013. "Viajando por los caminos del chamanismo mazateco: el chjota chjine y el tje'e”. In BARTOLOMÉ, M. \& BARABAS, A. (eds.): Los sueños y los días, chamanismo y nahualismo en el México actual, pp. 125-164. México: INAH.

MIRANDA, M.C.Q. \& ALVARADO, B. M. 1999. "La gente de nuestra lengua. El grupo etnolingüístico chjota énna (mazatecos)”. In BARABAS, A. \& BARTOLOMÉ, M. (eds.): Configuraciones étnicas en Oaxaca. Perspectivas etnográficas para las autonomias, pp. 11-53. México: INAH/INI. 
MIRANDA, Maria C. 2004. "Los huehuentones de Santa María Chilchotla. Una tradición mazateca”. In BARABAS, A., BARTOLOMÉ, M. \& MALDONADO, B. (eds.): Los pueblos indígenas de Oaxaca. Atlas etnográfico, pp. 64-65. México: INAH/FCE.

NEIBURG, Federico G. 1984. Identidad y conflicto en la sierra mazateca. El caso del Consejo de Ancianos de San José Tenango. México: Instituto Nacional de Antropología e Historia.

PEREZ QUIJADA, Juan. 1996. "Tradiciones de chamanismo en la Mazateca Baja", Revista Alteridades, 6(12):49-59.

RODRIGUEZ, María T. 2016. "Discursos de identidad y nuevos escenarios de la religiosidad mazateca”. Nueva Antropología, 30(84):73-89.

SCHAFER, Carol. 2012. La voz de las trece Abuelas. Ancianas indígenas aconsejan al mundo. Ediciones Luciérnaga: Barcelona.

TAUSSIG, M. 1987. Xamanismo, colonialismo e homem selvagem. São Paulo: $\mathrm{Paz}$ e Terra.

WASSON, Robert G. 1957. "Seeking the magic mushroom”. Life, 100-102, 109. 120.

\begin{abstract}
In this article we analyze the contemporary shamanism in Huautla from the case study of the grandmother Julieta Casimiro, one of the most outstanding chjota-chjine of the city, with which I had the opportunity to work for more than seven months during the fieldwork. Our presentation will be divided into three sections in which we present data of a different nature. In the first section we present a synthesis of the trajectory of the Grandmother Julieta. The second section systematizes information that is the result of direct observation, of having accompanied dozens of rituals with the holy children and of having participated as an auxiliary in several opportunities. In the third section I approach my own learning throughout this ethnographic experience, an ethnography from states of consciousness in rituals with 'holy children'.
\end{abstract}

Keywords: Shamanism, Rituals, Contemporary shamanism, Mazatec.

Recebido em janeiro de 2020.

Aprovado em julho de 2020. 